\title{
Uji Biokompatibilitas Nanofiber Komposit Kitosan/PVA Sebagai Pembalut Luka
}

\author{
Abdul Supriyanto $^{\left.1^{*}\right)}$, Minarti Liana Murni ${ }^{2)}$, Fitri Marlina ${ }^{3)}$, Dwi Pangga $^{4)}$ \\ ${ }^{1,2 \& 3)}$ Program Studi Pendidikan Fisika, FPMIPA, IKIP Mataram \\ *Email: abdulsupriyanto72@gmail.com
}

\section{Article History \\ Received: April 2018 \\ Reviewed: May 2018 \\ Key Words \\ Nanofiber; \\ Wounds; \\ Chitosan; \\ Biocompatibility}

Published: June 2018

\section{Sejarah Artikel}

Diterima: April 2018

Direviu: Mei 2018

Dipublikasi: Juni 2018

Kata Kunci:

Nanofiber;

Pembalut Luka;

Kitosan;

Biokompatibilitas

How to cite this article?

\begin{abstract}
[Title: Chitosan/PVA Composite Nanofiber Biocompatibility Test as a Wound Wrap]. This study aims to make chitosan-based nanofiber from NTB local crab shells. The manufacture of nonofiber is intended for application in the medical world as wound dressing. Wound dressing was developed from the basic ingredients of chitosan from NTB local crab shells. This research was conducted using the electrospining method, namely by making fibers from nano-sized chitosan. The resulting wound dressing was analyzed using FTIR. The results of this analysis show that chitosan has an area of absorption or transmittance in some chitosan groups so that it shows a positive alloy on chitosan and PVA as antibacterial in wound dressing.
\end{abstract}

\begin{abstract}
Abstrak
Penelitian ini bertujuan untuk melakukan pembuatan nanofiber berbahan dasar kitosan dari cangkang kepiting lokal NTB. Pembuatan nonofiber dimaksudkan untuk aplikasi dalam dunia medis sebagai pembalut luka. Pembalut luka dikembangkan dari bahan dasar kitosan dari cangkang kepiting lokal NTB. Penelitian ini dilakukan dengan menggunakan metode elektrospining, yaitu dengan membuat serat dari kitosan dengan ukuran nano. Pembalut luka yang dihasilkan dianalisa menggunakan FTIR. Hasil analisis ini menunjukan kitosan memiliki daerah serapan atau transmitansi pada beberapa gugus kitosan sehingga menunjukan paduan positif pada kitosan dan PVA sebagai antibaketeri pada pembalut luka.
\end{abstract}

Supriyanto, A., Murni, M., L., Marlina, F., Pangga, D. (2018). Uji Biokompatibilitas Nanofiber Komposit Kitosan/PVA Sebagai Pembalut Luka. Lensa: Jurnal Kependidikan Fisika, 6(1), 37-42.

\section{PENDAHULUAN}

Penelitian ini dilatarbelakangi oleh adanya keterbatasan dan mahalnya material penutup luka biologis yang dapat digunakan. Selama ini telah digunakan penutup luka biologis yang berasal dari kulit babi atau kulit jenazah manusia, namun bahan tersebut mahal dan hanya dapat digunakan untuk waktu yang singkat. Para peneliti sebelumnya telah banyak yang menunjukkan bahwa ternyata polimer alam sangat bagus dijadikan sebagai bahan dasar pembalut luka. Salah satu polimer alam tersebut adalah kitosan. Kitosan merupakan turunan dari kitin. Kitin diperoleh dari cangkang udang, cangkang kepiting, dan cangkang kerang yang telah melalui beberapa proses, yaitu demineralisasi dan deproteinasi.

Indonesia yang merupakan negara maritim memiliki kekayaan berupa kepiting yang sangat melimpah. Berdasarkan data Kementerian Kelautan dan Perikanan Republik Indonesia (2015) menjelaskan bahwa volume ekspor kepiting tahun 2014 dibandingkan 2013 mengalami pningkatan yang awalnya 359.304 ton menjadi 414.372 ton. Namun selama ini kepiting hanya dikonsumsi dagingnya saja. Sedangkan cangkangnya disia-siakan sehingga menyebabkan pencemaran lingkungan.

Berdasarkan permasalahan tersebut perlu adanya sebuah inovasi sebagai langkah penyelesaian. Melalui Program Kreativitas mahasiswa (PKM) ini disusun suatu langkah solusi yaitu dengan melakukan penelitian pembuatan nanofiber kitosan berbahan dasar cangkang 
kepiting sebagai pembalut luka dengan metode electrospining. Peneliti optimis penelitian ini akan berhasil karena akan dibimbing oleh Dosen Pembimbing yang berpengalaman dalam penelitian di bidang yang sama dan telah mendapatkan hibah penelitian dari Kemenristek DIKTI.

Penelitian ini dilakukan dengan tujuan pembuatan nanofiber sebagai pembalut luka berbahan dasar kitosan dari cangkang kepiting. Untuk mencapai tujuan tersebut, penelitian ini memiliki tujuan khusus yaitu a) Pembuatan nanofiber kitosan berbahan dasar cangkang kepiting, b) Aplikasi nanofiber kitosan hasil penelitian sebagai pembalut luka,

Penelitian ini penting untuk dilakukan, karena melalui penelitian ini permasalahan lingkungan yaitu masalah limbah cangkang kepiting dapat diminimalisir. Selain itu, melalui penelitian ini limbah cangkang kepiting dapat menjandi produk yang memiliki nilai jual yang tinggi, yaitu menjadi kitosan yang akan diaplikasikan menjadi pembalut luka. Penelitian ini diharapkan dapat meningkatkan ekonomi masyarakat. Kontribusi yang akan diberikan terhadap pembangunan nasional, yaitu hasil penelitian ini dapat menjadi modal bangsa Indonesia menjadi bangsa yang mandiri dalam hal ekonomi dan kesehatan.

Metode electrospinning dipilih dalam penelitian ini karena telah diakui oleh banyak kalangan merupakan teknik yang efektif, sederhana, dan cara mudah untuk mengontrol morfologi nanofiber (Charernsriwilaiwat dkk., 2010). Ramakrishna, S. dkk.(2005), dalam penelitiannya menyatakan bahwa electrospinning adalah teknik serbaguna dan hemat biaya untuk memproduksi nanofiber multi-fungsional dari berbagai polimer, polimercampuran, komposit, sol-gel, keramik, dll.

Hasil penelitian yang lain, Shi dkk. (2015) menyatakan bahwa electrospinning merupakan metode yang dapat diaplikasikan untuk pabrikasi bahan-bahan dalam ukuran nano 1 dimensi dengan bahan baku polimer, bahan anorganik dan komposit. Informasi yang didapat dari para peneliti inilah yang mengispirasi dan memotivasi pengusulan penelitian pembuatan nanofiber kitosan dengan metode electrospinning.

Kitosan dipilih sebagai bahan dasar dalam pembuatan pembalut luka dalam penelitian ini, mengingat melimpahnya limbah cangkang kepiting di Nusa Tenggara Barat. Peneliti sebelumnya telah berhasil membuat kitosan dari cangkang kepiting local NTB yang diaplikasikan untuk menyerap ion emas (Sabda dkk.,2017). Sebuah artikel yang berjudul "Chitosan based nanofibers, review" (Elsabee M.,Z. dkk., 2012) menjelaskan bahwa kitosan merupakan polimer alam yang memiliki potensi besar untuk diaplikasikan dalam berbagai bidang seperti biomedis, pengolahan air limbah dan beberapa aplikasi lainnya

Perkembangan teknologi nano melaju sangat pesat karena material dalam ukuran nano memiliki kelebihan dibandingkan dengan material dalam ukuran yang lebih besar, misalnya nanofiber memiliki karakteristik yang luar biasa seperti memiliki luas permukaan dan volume yang besar dan porositas yang tinggi dengan ukuran pori yang sangat kecil, sehingga nanofiber dapat berpeluang menjadi bahan untuk berbagai penerapan biomedical seperti template jaringan, prostheses medis, organ tiruan, dan pembalut luka dalam Ahmed dkk. (2016) dalam penelitiannya mengatakan bahwa kitosan merupakan biopolymer alam yang bagus digunakan sebagai bahan dasar pembuatan pembalut luka karena memiliki sifat biocompatible dan biodegradable di alam. Atas dasar informasi dari para peneliti inilah maka dilakukanlah penelitian pembuatan nanofiber kitosan sebagai pembalut luka dengan menggunakan metode electrospinning.

\section{METODE}

Penelitian tentang pembuatan nanofiber kitosan berbahan dasar cangkang kepiting ini dilaksanakan selama 5 bulan. Alur penelitian dapat dilihat pada Gambar 1. 


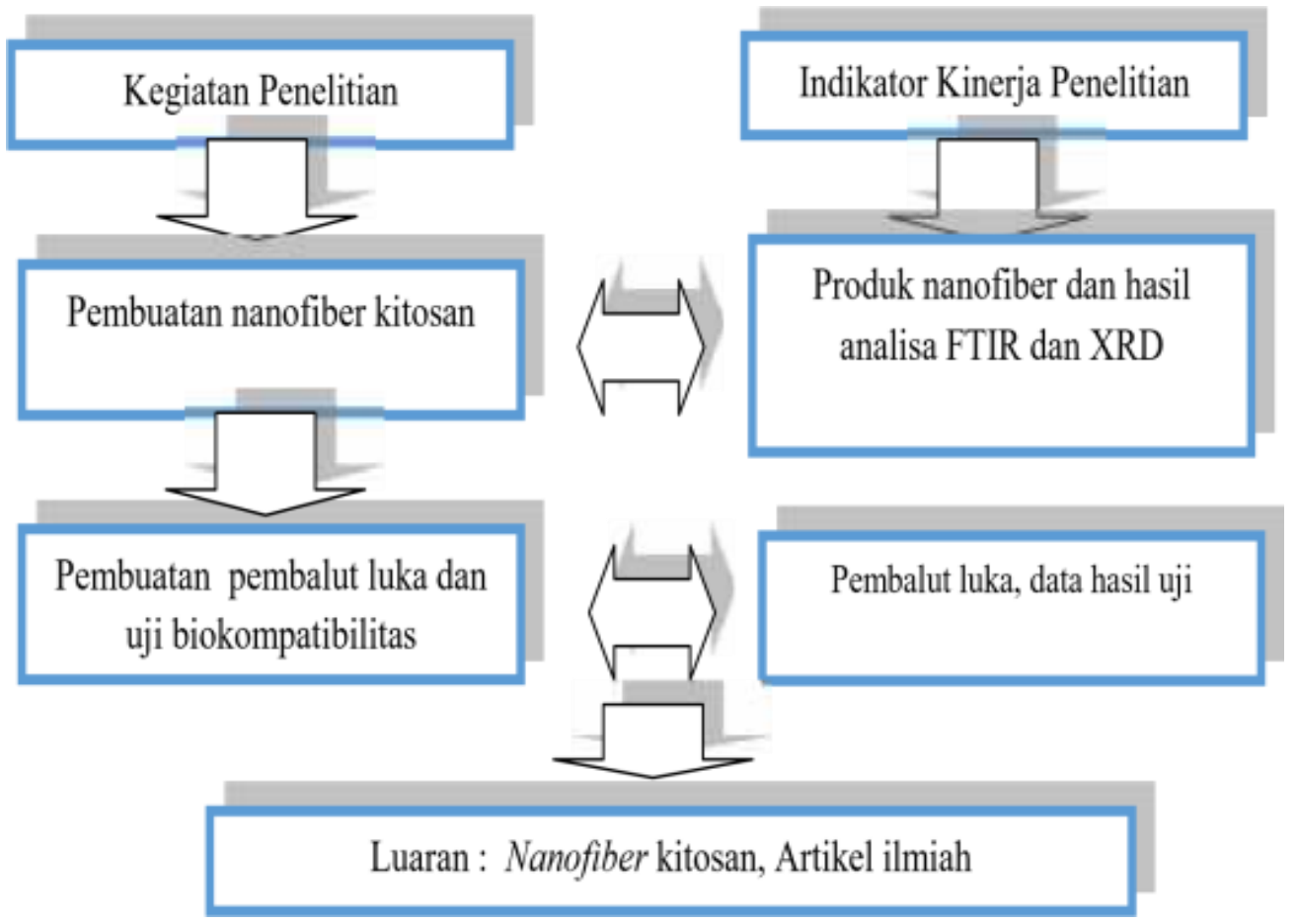

Gambar 1. Skema penelitian dan indikator kinerjanya

Sesuai dengan skema pada Gambar 1, penelitian ini dimulai dengan pembuatan nanofiber kitosan dari cangkang kepiting lokal NTB dengan metode electrospinning yaitu pada langkah ini dilakukan persiapan larutan yang akan dibuat nanofiber yaitu larutan antara PVA, asam asetat, dan kitosan. Larutan dibuat dengan kondisi sangat homogen dengan kekentalan yang tepat.

Nanofiber yang dihasilkan akan diaplikasikan sebagai pembalut luka. Adapun langkahlangkah penelitian secara detail yaitu:

a. Pembuatan Larutan

1) Pembuatan larutan $\mathrm{HCl} 1,5 \mathrm{M}$

2) Pembuatan larutan $\mathrm{NaOH} 3,5 \%$

3) Pembuatan larutan $\mathrm{NaOH} 60 \%$

b. Pembuatan Kitosan sebagai Pembalut Luka

1) Persiapan bahan limbah cangkang kepiting hingga menjadi serbuk berukuran 80 mesh.

2) Serbuk cangkang kepiting dihilangkan mineralnya (demineralisasi)

3) Penghilangan protein (deproteinasi)

4) Deasetilasi

c. Pembuatan nanifiber kitosan

1) Electrospinning

2) Melarutkan antara PVA, Asam Asetat, kitosan

d. Karakterisasi Nanofiber

Nanofiber hasil penelitian dianalisis dengan menggunakan FTIR untuk menunjukan bahwa kitosan-PVA memiliki perpaduan yang positif sebagai anti bakteri. Nanofiber dari suatu kitosan dibuaat dan diteliti dikarenakan memiliki sifat serta karakteristik seperti luas permukaanya yang besar dan ukuran pori-porinya yang kecil.

e. Uji Biokompatibilitas Nanofiber sebagai pembalut luka

Uji biokompatibilitas ini kemampuan mengetahui suatu pembalut luka untuk tidak menimbulkan respon biologis atau merugikan jika bahan diletakkan didalam tubuh.

Penelitian ini menggunakan alat-alat seperti Magnetic stirrer, Oven, Desikator, Timbangan analitik ohaus, Stop watch, FTIR, statif dan klem, Termometer, Pengaduk magnetik, Corong, , Pipet, Labu ukur, Gelas beker, seperangkat electrospinner.

Bahan-bahan yang digunakan dalam penelitian ini adalah Kitosan dari cangkang kepiting, $\mathrm{HCl}$ p.a, $\mathrm{NaOH}$ p.a, asam asetat, Aquadest, PVA (polyvinyl alcohol), alumunium foil. 


\section{HASIL DAN PEMBAHASAN}

Adapun hasil dan luaran yang telah di capai yaitu:

1. Kitosan dari Cangkang kepiting

Pada penelitian ini telah dilakukan pembuatan kitosan dari cangkang kepiting lokal NTB seperti pada terlihat pada Gambar 2.

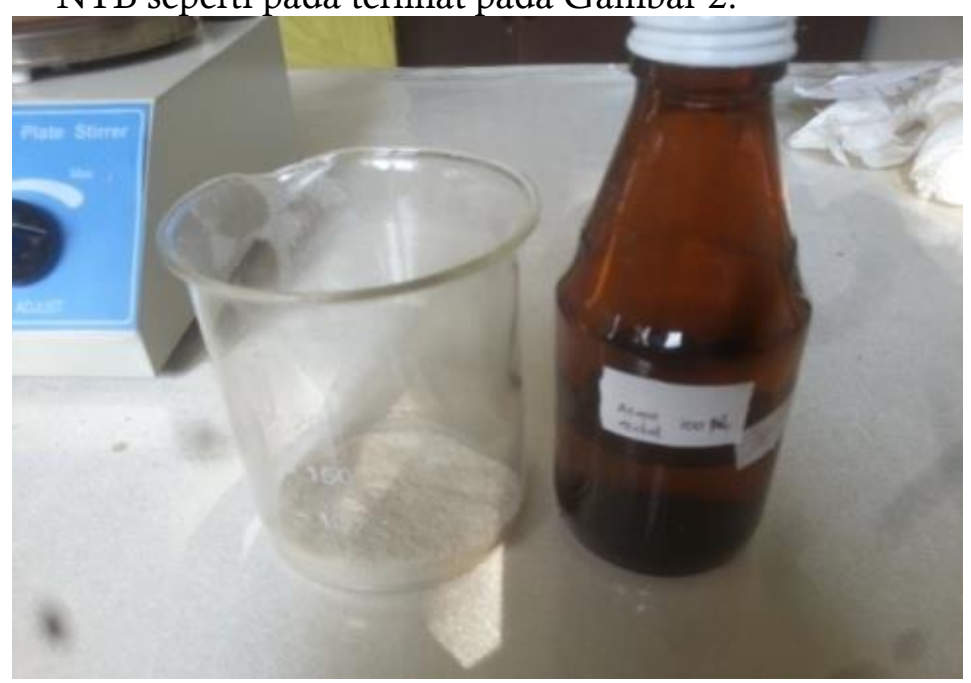

Gambar 2. Kitosan dan asam asetat

Pada penelitian ini dihasilkan kitosan dari cangkang kepiting setelah melakukan 3 proses yaitu dimineralisasi, diproteinisasi, dan deasetilasi. Cangkang kepiting ini terbukti memiliki kandungan mineral berupa kalsium fosfat yang berarti berasal dari limbah hasil laut. Mineral ini harus dihilangkan untuk mengambil kitin atau kitosan yang terdapat pada cangkang kepiting. Hasil dari diproteinisasi berhasil mengurangi protein pada cangkang kepiting.

2. Membran komposit kitosan-PVA

Setelah melakukan pengadukan kitosan-PVA dan asem asetat akan menghasilkan membran komposit seperti pada Gambar 3.

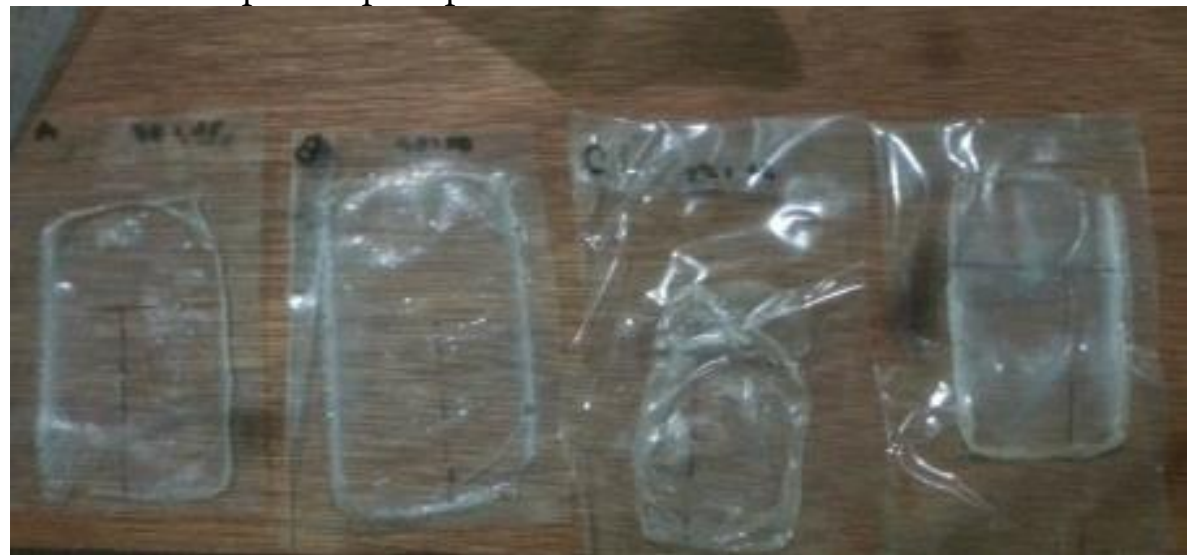

Gambar 3. Membran Komposit Kitosan-PVA

Membran komposit kitosan-PVA yang dihasilkan dibuat dengan teknik inversi fasa yang merupakan polimer, pelarut dan non pelarut, dimana sebuah polimer di rubah secara terkendari dari fasa cair kefasa padat yang dilakukan dengan melarutkan 1,5 kitosan dalam 50 asam asetat 1 $\%$ menggunakan pengaduk magnetik selama 2 jam, selanjutnya melarutkan 1,5 PVA dalam 50 $\mathrm{ml}$ aqudes menggunakan pengaduk magnetik selama dua jam, dimana 1 jam pertama disertai dengan pemanasan. Setelah itu larutan kitosan dan PVA yang sudah terbentuk dapat dicampurkan keduanya pada wadah pencetakan. Kemudian wadah pencetakan tersebut didiamkan pada suhu kamar selama dua hari sehingga menguapkan pelarutnya dan membentuk pori-pori pada membran.

3. Nanofiber 
Nanofiber komposit kitosan setelah diperoleh kitosan, maka produk ini digunakan untuk pembuatan nanofiber kitosan menggunakan metode elektrospining diperoleh nanofiber kitosan seperti terlihat pada Gambar 4.

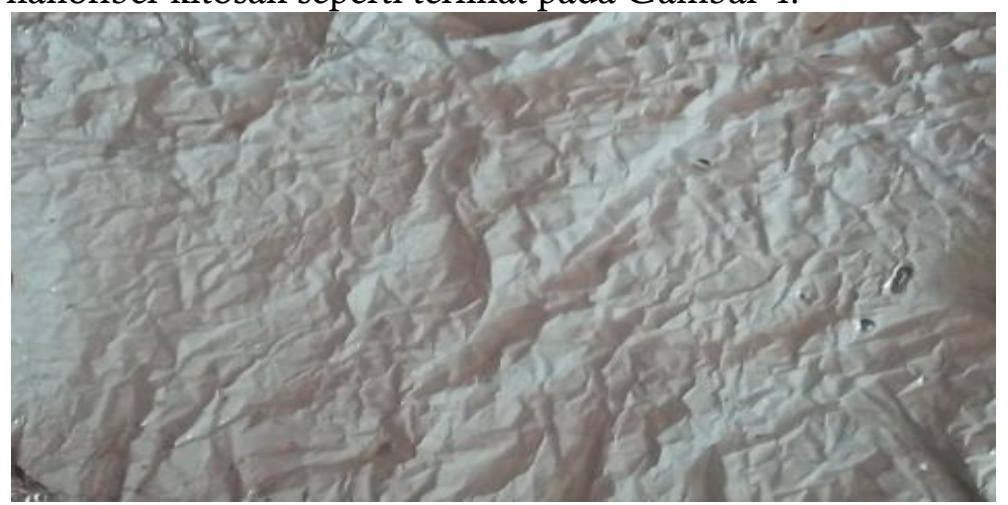

Gambar 4. Nanofiber Kitosan

Nanofiber komposit kitosan ini dibuat menggunakan metode elekstropinning dengan prinsip memanfaatkan gaya elektrostatis yaitu tarik menarik muatan posirif dan negatif yang menggunakan tegangan tinggi DC hingga $20 \mathrm{Kv}$.

\section{KESIMPULAN}

Berdasarkan hasil penelitian ujibiokompatibilitas nanofiber komposit kitosan sebagai pembalut luka ini terdapat beberapa hasil yang dicapai yaitu kitosan atau kitin, membran komposit kitosan-PVA dan nanofiber komposit kitosan. Kitosan diambil memlaui proses dimineralisasi, diproteinisasi dan dieastetilasi.

\section{UCAPAN TERIMA KASIH}

Terima kasih sebesar-besarnya kami sampaikan kepada:

1. Ristek Dikti yang telah memberikan bantuan dana sehingga PKM Penelitian ini dapat terlaksna

2. Fakultas Pendidikan Matematika dan IPA atas dukungan moral dan administrasi sehingga PKM Penelitian ini dapat terlaksana.

3. Dosen Pendamping yang telah membimbing dan mendukung kami sehingga PKM Penelitian ini bisa diterima oleh Ristek Dikti

4. Semua pihak yang turut membantu dalam proses penelitian ini

\section{DAFTAR PUSTAKA}

Ahmed S., Ahmad M., (2016), Chitosan Based Dressing for Woung Care, Immunochemistry\& Immunopath ology, http.//: dx.doi.org.

Charernsriwilaiwat, N., Opanasopit, P., Rojanarata, Th., Ngawhirunpat, T., Supaphol, P. (2010). Preparation and characterization of chitosanhydroxy benzotriazole/polyvinyl alcohol blend nanofibers by the electrospinning technique, Carbohydrate Polymers 81, 675-680

Ciechanska, D. (2004). Multifungsional Selulosa bakteri/Chitosan Composite Materials for Medical Applications. Fibres \& Textiles in Eastern Europe.

Elsabee, M.Z., Naguib, H.F., Morsi, R.E., (2012). Chitosan based nanofibers review. Materials Science and Engineering: C 32, 1711-1726.

Hoenich, N. (2006). Cellulose for Medical Applications. Bioresources.

Huang et al., (2003), A Review on Polymer Nanofibers by Electrospining and Their Applications in Nanocomposite, Composites Science and Technology

Lestari Indah. (2018). Uji Mekanik Membran Kitosan Berbahan Dasar Cangkang Kepiting: Mataram

Ramakrishna S., R. Jose, P.S. Archana, A.S. Nair, R. Balamurugan, J. Venugopal, W. E. Teo, (2010), Science and engineering of electrospun nanofibers for advances in clean energy, water filtration and regenerative medicine, J. Mater. Sci, vol. 45, pp. 6283-6312. 
Shi X., Zhou W., Ma D., Ma Q., Bridges D., (2015), Electrospinning of Nanofibers and Their Applications for energy Devise, Hindawi Publishing Corporation, Journal of Nanomaterials.

Voudrias E., Fytianos F., Bozani E., (2002), Sorption Description isotherms of Dyes from aqueous solutions and Waste Waters with Different Sorbent materials, Global Nest, The Int.J, 4(1),75-83 